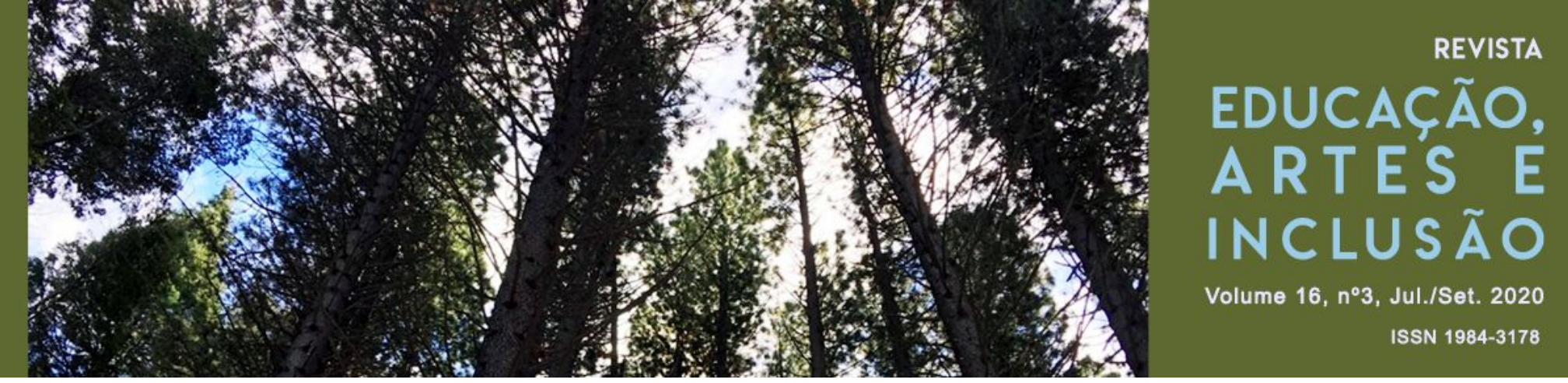

\title{
A percepção do sensível e o ensino da arte na contemporaneidade
}

\section{The perception of sensitivity and the teaching of art in contemporaneity}

DOI: http://dx.doi.org/10.5965/198431781632020368

Josélia Schwanka Salomé

Universidade Tuiuti do Paraná joselia.salome@hotmail.com

Maria Cristina Mende

Universidade Estadual de Ponta Grossa mariacristinamendes1@gmail.com

\section{RESUMO}

Este artigo tem o objetivo de apontar possíveis caminhos para as particularidades da construção de conhecimento pelo sensível. $O$ trabalho com a arte na educação pode se apresentar como uma das possibilidades de trabalho na perspectiva da superação da formação unilateral ao aliar o desenvolvimento do conhecimento inteligível ao saber sensível. As inquietações aqui presentes refletem a importância da educação estética na formação humana diante dos interesses para uma formação voltada à adequação mercadológica implantada na educação, em seus diversos níveis. Entendemos que diminuição e a possivel extinção da educação pelo sensível certamente acarretará o aumento da competitividade e, consequentemente, da violência e, sendo assim, repensar estratégias educacionais e fomentar a discussão acerca do valor da arte no ensino formal é uma necessidade urgente no país. Deste modo, concluímos que, se a arte não pode, sozinha, humanizar, pode proporcionar o estranhamento e a dúvida, a fuga das convenções e da submissão automática às práticas sociais hegemônicas.

Palavras-chave: Educação Estética. Saber Sensível. Ensino da Arte.

\section{ABSTRACT}

This article aims to point out possible ways of valuing singularities in the construction of knowledge by the sensitive. The work with art in education can be presented as one of the possibilities of working in the perspective of overcoming unilateral formation by allying the development of intelligible knowledge and sensible knowledge. The worries presented here reflect the importance of aesthetic education in human formation in the face of the interests for a training aimed at the market adaptation implemented in education, at its various levels. We understand that the reduction and the possible extinction of education by the sensitive will certainly increase the competitiveness and, consequently, the violence and, thus, rethinking educational strategies and fomenting the discussion about the value of art in formal education is an urgent need in the country. In this way, we conclude that if art alone can't promote humanization, it can provide strangeness and doubt, the escape of conventions and of automatic submission to hegemonic social practices. 
